\title{
10. THE OCCURRENCE OF DEEP WATER GLAUCONY FROM THE EASTERN PACIFIC: THE RESULT OF IN SITU GENESIS OR SUBSIDENCE? ${ }^{1}$
}

\author{
G. S. Odin, Département de Géologie Dynamique, E.R.A. 604, Université Pierre et Marie Curie, 75230 Paris, France \\ and \\ J. F. Stephan, Université de Bretagne Occidentale, 29283 Brest, France
}

\begin{abstract}
During the analysis of "glaucony" recovered during Leg 66, off Mexico, we reviewed the data on previously studied glaucony layers in active margin areas.

We found the depth of Leg 66 glaucony sediments to be significantly greater than conventionally assumed appropriate to their genesis $(100-500 \mathrm{~m})$. Accordingly, we hypothesize their occurrence at unusual depth to be due to (1) transport of shallow sediments and redeposition at greater depths, (2) margin subsidence, or (3) genesis at greater depth than is generally assumed.

For the area off Mexico, we reject (1). (2) has already been verified in Japan and is possible as an explanation for the present phenomenon without excluding (3), which we investigate in this chapter.
\end{abstract}

\section{RÉSUMÉ}

A l'occasion de l'étude de glauconies prélevées durant le Leg 66 au large du Mexique, une revue des gisements de glauconie connus aux abords de marges actives est effectuée. On constate que, dans cette situation spécifique, la profondeur actuelle des sédiments glauconieux est très supérieure à la profondeur généralement admise pour leur genèse $(100$ à $500 \mathrm{~m})$. Les trois hypotheses, (1) transport des grains verts des faibles vers les fortes profondeurs; (2) subsidence de la marge après genèse des grains verts; et (3) genèse réellement profonde sont discutées. Au large du Mexique l'hypothèse (1) est rejetée. L'hypothèse (2) a été vérifiée au Japon et serait possible au large du Mexique sans que l'hypothèse (3) puisse être rejetée. Le travail introduit un programme de recherche sur le même objet étendu à toutes les marges actives péripacifiques.

\section{INTRODUCTION}

The commonly held view that the authigenic process of glauconitization is limited to rather shallow depthsof one to several hundred meters-needs to be reexamined in the light of a growing number of recent discoveries of glaucony at much greater depths on Pacific margins. In this chapter we summarize these discoveries, outline the record of glauconitization in Leg 66 cores, and attempt to explain its deep occurrence. We consider three possibilities:

1) Glaucony grains at depths greater than about 500 meters have been redeposited by turbidity currents or wafted downslope by bottom currents;

2) Glauconitization originally occurred at depths of several hundred meters, but rapid subsidence of margins occurred subsequently.

3) Glaucony at great depth is formed in situ, in which case the common view of the normal depth of glauconitization needs to be modified.

We follow Odin and Matter (in press) in using the new term "glaucony" (plural: glauconies) for green grains having diverse mineralogical components with wholly authigenic glauconitic smectite and highly evolved glauconitic mica as compositional end-members. We consider this term preferable to "glauconite," which has been used to describe both a micaceous ma-

\footnotetext{
${ }^{1}$ Initial Reports of the Deep Sea Drilling Project, Volume 66.
}

rine clay mineral and a green pelletal sedimentary grain, thereby causing confusion in the literature (Odin and Létolle, 1980).

\section{REVIEW OF GLAUCONY OCCURRENCE AND GLAUCONITIZATION}

\section{Depth of Accumulation in Present Oceans}

Most glauconitic accumulations on modern continental margins occur between about 75 and 500 meters. The majority lie within the 100-200 meter range and the richest occur at about 200 meters (Odin, 1973; Odin and Matter, in press). This apparent restriction of glaucony to depths of less than 500 meters may be a product of the present topographic and circulatory patterns of continental margins and oceans. We emphasize that such restrictions may not have pertained in the past.

Not all glauconitic sediment occurs in this relatively shallow zone. Dredging cruises at the end of the nineteenth century recovered green grains (at more than $1000 \mathrm{~m}$ ) in various areas (Collet, 1908): one sample from the Mediterranean, off Morocco; one from north of Cuba; various samples from south of the Sunda Islands of Sumatra and Timor; and others from offshore Japan, east of New Zealand, between the Falkland Islands and the Rio de la Plata.

The last three marine accumulations have been studied again recently. On both sides of Japan the proportion of glaucony is higher than $5 \%$ in various sediments at more than $2000 \mathrm{~m}$ (Leg 31, Sites 293, 297, 298, and 
299, Karig et al., 1975). Glaucony occurs in the Pleistocene (which is at least $350 \mathrm{~m}$ thick) but has not been recovered in older strata. The green grains have still not been analyzed, but preliminary studies have shown that they are mixed with faunas indicating shallower water than the present depths; thus glauconitization itself may have occurred at shallower depths too.

East of New Zealand, the top of the Chatham Rise (Fig. 1) lies between 200 and 400 meters and is covered by glaucony-rich sediment along a $400-\mathrm{km}$ strip (Norris, 1964; Cullen, 1967). To the north and south of the rise glaucony was collected down to depths of more than 1000 meters. Glauconitization probably took place from latest Miocene times through the present day. Slow sedimentation or, possibly, winnowing of unconsolidated sediments has produced a highly glauconitic sand in the shallowest part of the rise. It seems most likely to us that the deepest glaucony is explained either by marginal subsidence of the rise or by redeposition on the sides of the rise. The greater abundance of glaucony at lower depths agrees with the second alternative.

East of Patagonia, the Scotia Ridge extends on a submarine ridge linking South America to the Antarctic continent (Fig. 2). Here glaucony is locally abundant at more than 500 meters water depth. The greatest proportion of green grains in sediment samples recovered $(35 \%$ of the whole sediment) occurs at a depth of nearly 2000 meters (Bell and Goodell, 1967). Although we do not have much information about this area, and at the moment it is not possible either to explain the presence of these green grains or to know the conditions of genesis, we emphasize that the area is tectonically active.

It is important to examine next any geochemical and sedimentological constraints that may confine the glauconitization process to a restricted depth.

\section{The Process of Glauconitization}

Given the requisite chemical milieu, glauconitization occurs within sedimentary particles, of detrital or biogenic origin, as they are slowly degraded on the seafloor (Odin, 1975a). Efficient ionic exchange proceeds in semiconfined microenvironments within the grain. Glauconitic minerals so produced begin with smectite; continuing slow recrystallization produces increasing potash-rich species until glauconitic mica is finally produced (Velde and Odin, 1975; Odin and Matter, in press). The time necessary to form a nascent glaucony is probably $10^{3}-10^{4} \mathrm{y}$., and the glauconitic mica, or highly evolved glaucony, is produced in about $10^{5} \mathrm{y}$.

Glauconitization can therefore only occur in open marine areas, far from significant input of terrigenous sediment. Glaucony degenerates in contact with highly oxygenated seawater, especially in tropical latitudes.

\section{Depth of Genesis}

Dependence on lack of fluvial influence and low levels of oxygen in bottom waters precludes glaucony genesis along the coast at depths of less than 30 to 50 meters. Further refinement of the upper limit is possible, because only little-evolved glaucony (Odin and Matter, in press) had time to grow above 110-120 meters since the Holocene transgression. Maximum depth is much more complicated to estimate. Great depth of genesis cannot be excluded because the requisite conditions for supply of plentiful ions, especially iron, exist on continental slopes, provided iron is not trapped across the continental shelf (Odin, 1975b). But renewal of sea bottom water is necessary for glauconitization, both because it provides new ions for crystal growth and because it prevents reducing conditions,

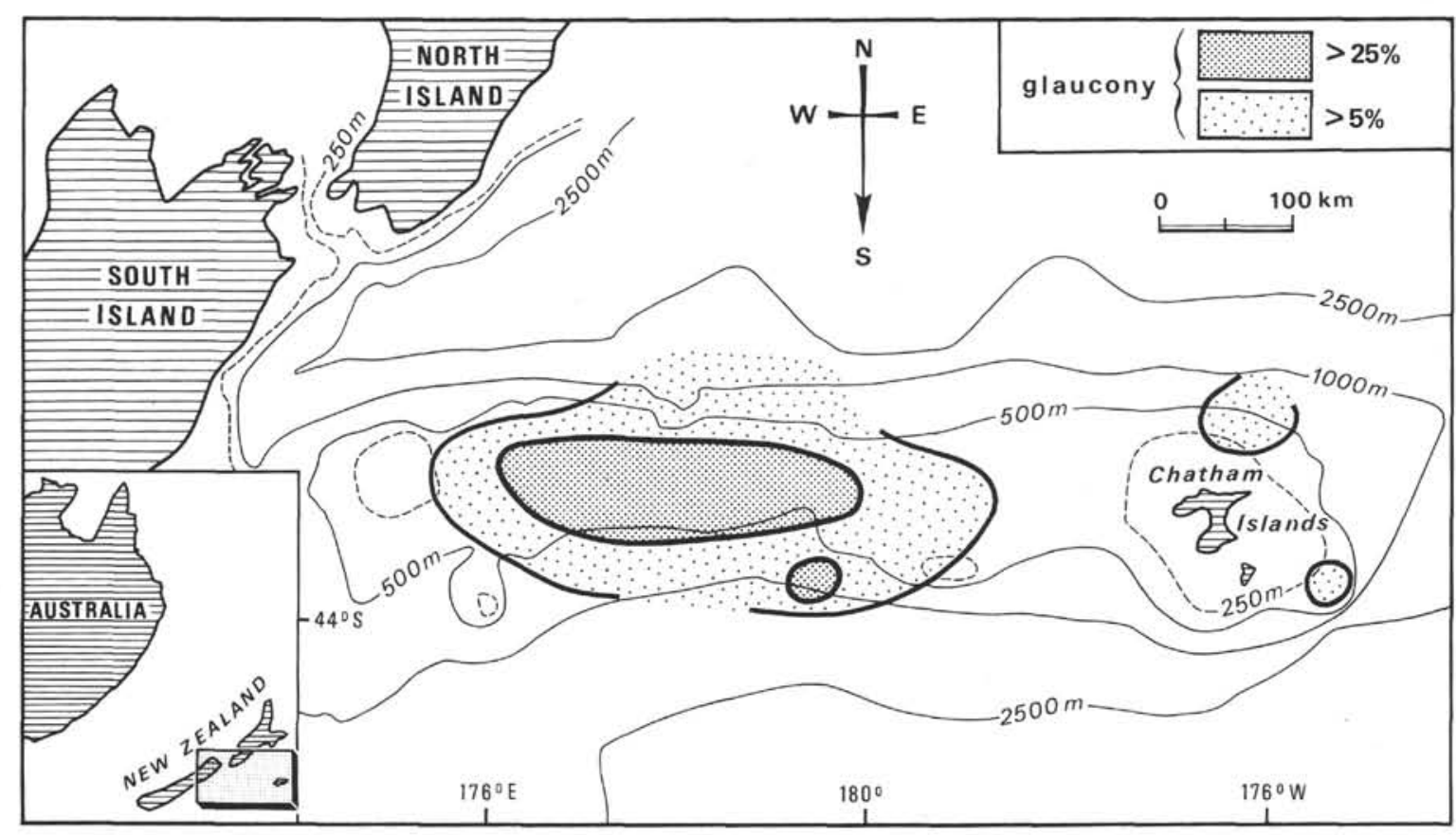

Figure 1. Distribution of glaucony in surface sediments on the Chatham Rise (after Norris, 1964, and Cullen, 1967). 


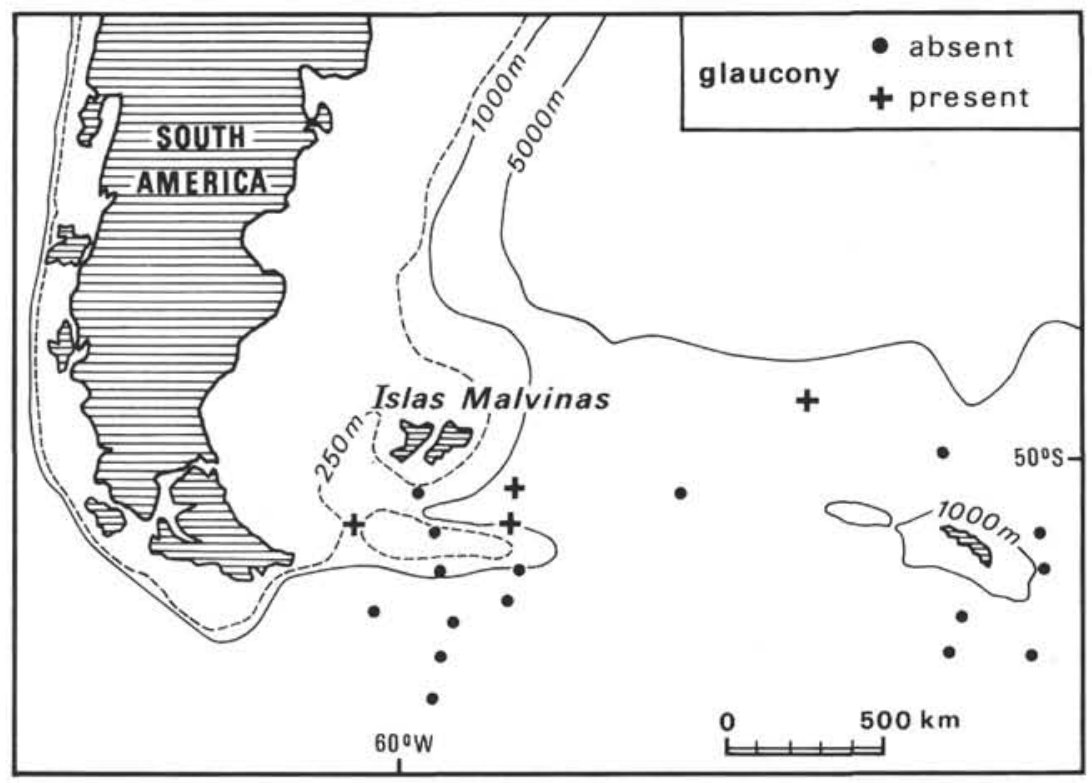

Figure 2. Distribution of glaucony in the surface sediments on the Scotia Ridge (after Bell and Goodell, 1967).

which would stop the growth of glauconitic minerals where iron is trivalent $\left(\mathrm{Fe}^{3+}\right)$. For this reason glauconitization cannot occur in a closed submarine depression.

The main restriction on the maximum depth of glauconitization is the host material. Every sedimentary particle with a size of 100 to $1000 \mu \mathrm{m}$ can host semiconfined microenvironments after a period of alteration, but there are in fact four major types: calcareous biogenic debris, coprolites, mineral debris, and microfaunal tests.

The calcareous biogenic clasts (shell fragments, echinides articles or fragments, and the like) as well as coprolites are formed in abundance at depths of less than 200 meters but can easily be transported into deeper areas. Fragments of detrital minerals can be transported to very deep water if heads of submarine canyons approach very near the coast: this is the situation off Mexico in the Leg 66 area. At the same time volcanic eruptions provide ash and lapilli over a large marine area at all depths. Finally, tests of calcareous microfaunas can be abundant and sufficiently dissolution-resistant to host the glauconitization process.

In summary, there are numerous reasons why glauconitization occurs at depths of less than 500 meters: presence of a continental platform at less than 200 meters, abundance of initial substrates, and ease of ion exchange. But we cannot at present discount the possibility of the process occurring at depths down to 1000 to 3000 meters, particularly in zones where the continental shelf is narrow or absent. Finally, lack of sufficient investigation alone may account for the failure to demonstrate in situ genesis of glaucony at depths greater than 500 meters.

\section{GLAUCONY OF THE NORTH AMERICAN PACIFIC MARGIN}

North of the Vancouver islands glaucony has been collected by dredging in only one sample, the deepest taken at $\mathbf{4 0 0}$ meters. In that sample glauconitization occurred in recent times in microfaunal chambers and probably in coproliths too, forming nascent to slightly evolved glaucony (Murray and MacKintosh, 1968).

During Leg 18 (Kulm et al., 1973), Site 176, $280 \mathrm{~km}$ south of Vancouver, was drilled near the coast to a depth of 193 meters, sub-bottom. Glaucony was present in Pleistocene sands and clays 20 meters downhole.

Since 1873, glaucony has been dredged at numerous locations along the Pacific coast south of Cabo San Lucas (Fig. 3). Collet (1908) quoted glaucony only at depths of less than $1800 \mathrm{~m}$ : at 914 and 1280 meters off Mariato Point, Panama. In most cases the green grains represented the glauconitization of foraminiferal chamber infillings and were only slightly evolved.

In Monterey Bay, California, glaucony is common on the continental slope and on the walls of the Monterey Canyon at 100 to 500 meters depth. No samples were collected from deeper sediments. A significant portion of these green grains derives from the evolution of detrital micas (Galliher, 1935). But some of these, confusingly named "glauconitic pellets" clearly appear as chloritized micas on the shelf (Hein et al., 1974). These last authors and Odin (1972) showed that in fact mica was only one of a number of possible host minerals in the Monterey Bay area. The glauconitization process is probably Recent in age.

According to a review by Pratt (1963), glauconitic sediments are widely distributed on the seafloor off Southern California in areas with low sedimentation rates. Glaucony is present in both shallow and deep environments. Pratt has determined that abundant green grains have a patchy distribution in the Santa Monica Bay and the Santa Barbara shelf, around and just below the shelf break near 200 meters depth. Farther north, glaucony was collected from a NE-SW traverse off Point Arguello (see also Yeats et al., in press). Green grains are abundant ( $70 \%$ of the sediment) at depths of 


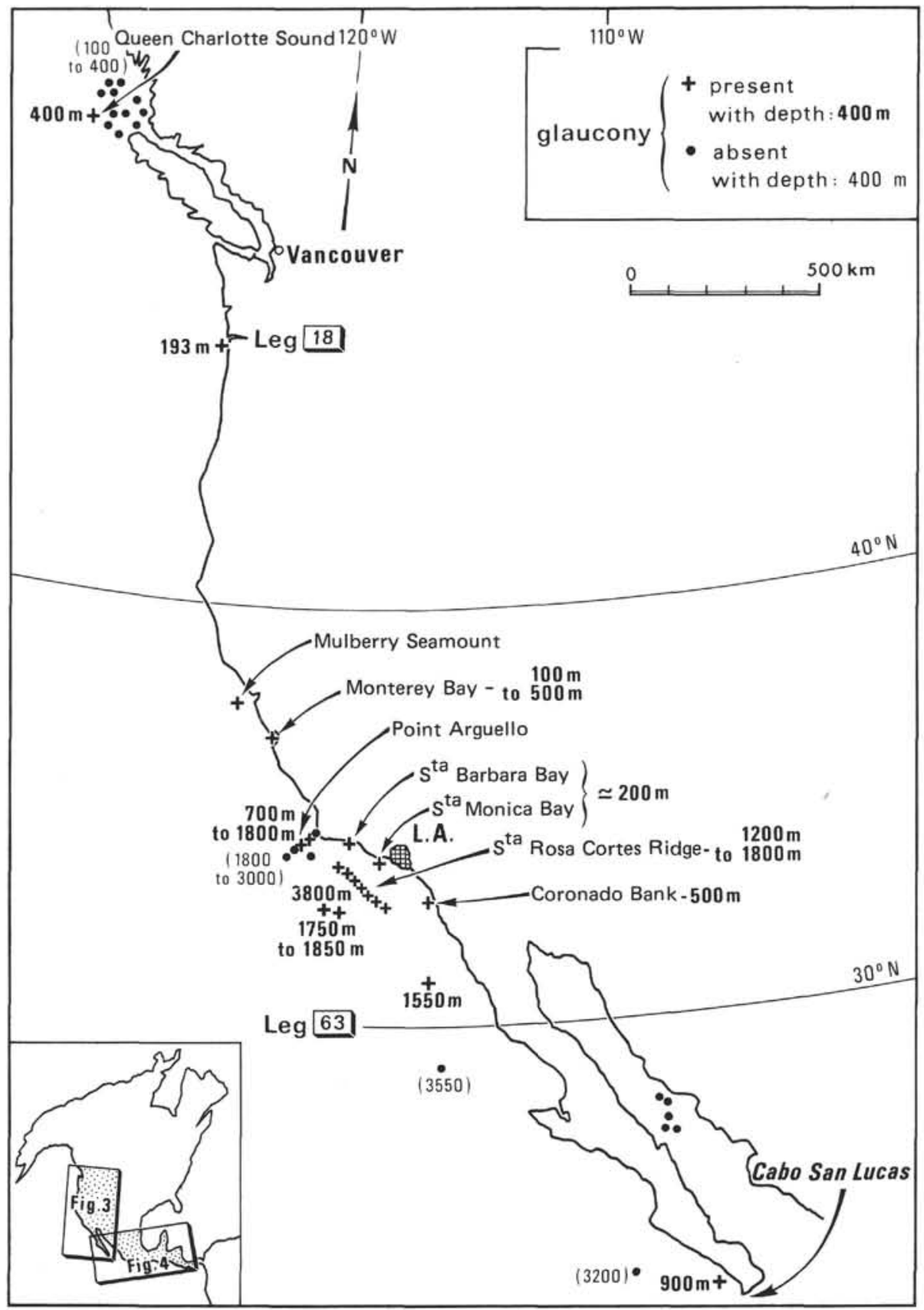

Figure 3. Distribution of glaucony off the North American coast. $(+=$ water depths at which Quaternary glaucony has been found, $\bullet=$ absence of glaucony; depths are in parentheses).

700 and 900 meters, present $(20 \%$ of yellow green grains) at 1800 meters, and absent at greater depths.

South of Santa Barbara nascent to little-evolved glaucony is common on the Santa Rosa Cortes Ridge at depths of 1200 to 1800 meters. Northwest of the westernmost San Miguel island evolved glaucony was recognized at 245 meters. The glaucony of the ridge $(5-20 \%$ of the sediment) comes from glauconitization of foraminiferal infillings and is also present as the filling of minute channels bored in pelecypod shells. Many foraminiferal tests, including large benthic species of Cassidulina and Elphidium characteristic of the outer shelf, are filled with green material. Uvigerina (and Glo- bigerina), presently lying at depths greater than 1500 meters on the continental slope, are also filled. The age of the glauconitization is probably diverse. Off Santa Barbara late Pliocene rocks showing glauconitic infillings lie just below Recent soft sediments; relict foraminifers suggest reworking. On the coast, the Palos Verdes Hill series are Pleistocene emerged sediments containing eyolved glaucony. Well-dated Pleistocene and Recent sediments from Coronado Bank (about $500 \mathrm{~m}$ deep) off San Diego are also rich in green foraminiferal infillings. Glaucony has been considered authigenic because the filled foraminifers are preserved in the same environment in which they lived (i.e., Cassiculina fau- 
nas from Santa Monica Bay, Santa Rosa Cortes Ridge, Coronado Bank).

Glaucony was also collected from isolated volcanic seamounts such as Rodriguez Seamount off Southern California and Mulberry Seamount off San Francisco.

In summary, glaucony appears in situ off California at present depths of 100 to 1800 meters. Frequently glaucony is linked with shallow depth alone.

The data from Leg 63 (Yeats et al., in press, and Fig. 3 ) cited traces of glaucony at Site 467 , drilled at 2128 meters water depth. The most glauconitic horizon $(30 \%$ of green grains in the whole rock) is middle Miocene; other Miocene, Pliocene, and thick Quaternary deposits contain less than $2 \%$ of green grains. At Site 468 (1737 m), Quaternary deposits are reduced to a few meters and the proportion of glaucony is as high as $6 \%$ of the whole sediment. The underlying Miocene and Pliocene deposits are glaucony-rich too $(2-10 \%$ of the whole sediment). In most cases glaucony is associated with numerous foraminiferal tests. At Site 469 (3790 m) Quaternary deposits are $\mathbf{4 0}$ meters thick. Several glauconitic foraminiferal ooze horizons were observed in deposits of this age as well as in those of the late Pliocene and Miocene.

Farther south, at Sites 470 to 483 (3100-3830 m), no significant proportion of glaucony was observed. The only rich horizon ( $25 \%$ of green grains) is dated as early Pliocene, at Site 473. During Leg 64 (Curray et al., in press, and Fig. 4) Sites 474 to 476 were drilled off Cabo San Lucas. At Site $474(3023 \mathrm{~m})$ glaucony is absent from the rather thick (400-m) Quaternary deposits. Nearest the coast, at Site $475(2631 \mathrm{~m})$, the 60 meters of Quaternary deposits are glauconitic. The glauconitization process occurs in infillings of microtests, but the richest horizon ( $30 \%$ of green grains) is associated with sponge spicules. Another rich horizon is (early?) Pliocene.

Site $476(2403 \mathrm{~m})$, near Site 475 , has Quaternary glauconitic horizons very rich in foraminiferal tests (30\% of the whole sediment); Quaternary deposits here are 90 meters thick. Below the Quaternary a horizon with 30 to $40 \%$ of green grains is associated with a rich foraminiferal fauna of essentially benthic origin; many of the test chambers are filled with green material. Glaucony is also present at the base(?) of the Pliocene. No significant glaucony was found at sites in the Gulf of California.

Ross (1971) reported the presence of glaucony in surface sediments off Manzanillo (Fig. 4) at 900 to 1800 meters depth. Green grains were collected from the upper slope and are said to be associated with a structural high rather far from the main source of detrital sediments in the area.

\section{GLAUCONY OFF CENTRAL AMERICA}

\section{Legs 66 and 67 Data}

During Leg 66, eight sites were drilled along a transect of the Middle America Trench, off Ometepec City, Oaxaca (Mexico) (Fig. 4). Going west, Sites 493, 489,
$490,492,491,488,486$, and 487 are located at water depths of $645,1240,1761,1935,2883,4254,5140$, and 4764 meters, respectively. No glaucony was observed at the three deepest sites, and at Sites 491 and 493 (the shallowest) only traces occur.

In Holes 489 and 489A the recent Quaternary deposits (NN20/NN21 zones) are 6 to 8 meters thick. They disconformably overlie a thick lower Miocene sequence of NN4 at the top. The break in sedimentation represented by the disconformity lasted nearly $15 \mathrm{~m} . \mathrm{y}$. The Quaternary sediment is a glauconitic foraminiferal muddy silt. Green grains occur in mudstone and muddy silt horizons in the lower Miocene sequence (NN1-NN4).

In Hole 490 the Quaternary deposits are thicker (145 $m)$ than at Sites 489 . There is no faunal break with the underlying Pliocene and upper Miocene(?) sediments. Glaucony is present in several discrete horizons down the sequence. Shipboard smear slides show 5 to $20 \%$ of green grains in the top two meters and at 27, 185, 265, and 383 meters downhole.

In Holes 492 and 492A the Quaternary and upper Pliocene deposits are only 15 to 20 meters thick. The lower Pliocene sediments lie above a thick upper Miocene sequence. Glaucony occurs in rich horizons situated between 2 and 44 meters sub-bottom.

During Leg 67, off San José, Guatemala, seven sites were drilled (Aubouin and Azéma, personal communication). Going west, Sites 496, 497, 494-498, 499-500, and 495 were drilled at water depths of 2049, 2347, $5472-5478,6105-6090$, and 4140 meters, respectively.

In Hole 496 glauconitic horizons occur throughout a thick $(235 \mathrm{~m})$ Quaternary diatomaceous mud. Glaucony is associated with high concentrations of foraminifers. In the rather thin underlying Pliocene and Miocene deposits, some horizons contain up to $80 \%$ green grains and glaucony is abundant in numerous other horizons. Hole 497 also contains glauconitic horizons in a thick Quaternary sequence as well as in the underlying, thick Pliocene deposits. In Holes 494 and 494A a thick Quaternary diatomaceous mud is also glaucony-rich. Toward the ocean the Quaternary and Pliocene sediments are also slightly glauconitic but the Miocene deposits are not. Glaucony also occurs in Quaternary deposits in the deepest holes, 499 and 499A.

In summary, the glaucony observed during Leg 66 and 67 is situated at depths similar to those at which it occurred from San Francisco south to Panama. Off Mexico, however, there is no glaucony at less than 1200 meters, it was observed at exceptional depths $(5529 \mathrm{~m}$ in Hole 494 and $6130 \mathrm{~m}$ in Hole 494A) and off Guatemala.

Glauconitization occurred essentially in microfossil chambers.

\section{Leg 66 Glaucony}

In order to obtain a sufficient quantity of green grains for analyses, we selected 25 samples from Holes 489, 489A, 490, 492, and 492A, using the Initial Core Descriptions and the results of preliminary examination of 100 available samples. As green grains are generally heterogeneous in color, evolutionary stage, and diffrac- 


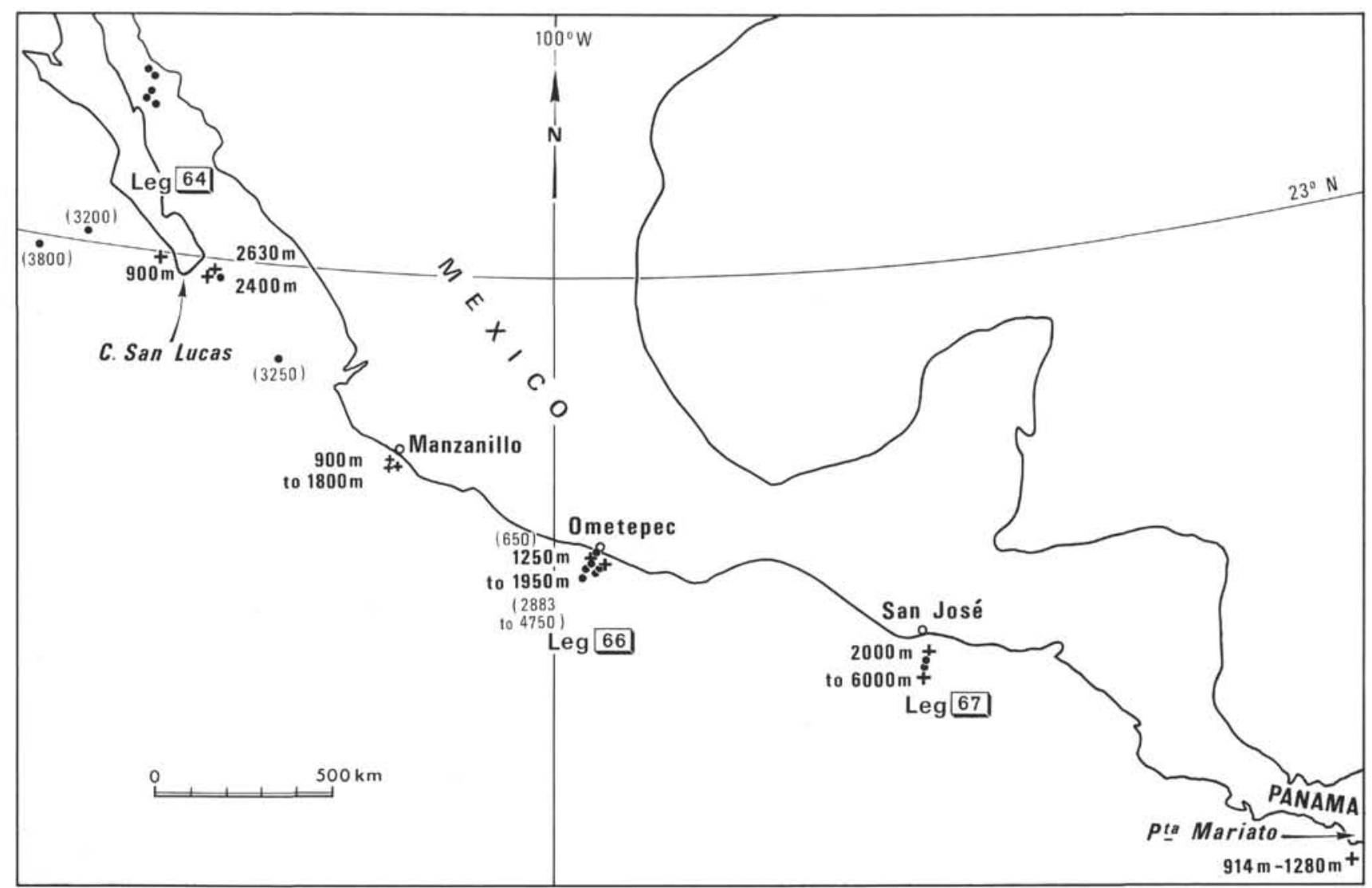

Figure 4. Distribution of glaucony off Central America. (Symbols as for Figure 3.)

tometric characteristics in a given sample (especially in little-evolved sediments), it is useful to split the green grain fraction itself into various mineralogical types.

\section{Sand-Sized Fractions}

The samples-either nearly $20 \mathrm{~g}$ in tubes or $3-5 \mathrm{~g}$ in bags-are first washed on a $35-\mu \mathrm{m}$ sieve. The two fractions are dried at a temperature less than $70^{\circ} \mathrm{C}$ and further sieved to 0.5 and $0.16 \mathrm{~mm}$. Usually there is little or no glaucony smaller than $0.16 \mathrm{~mm}$ or larger than 0.5 $\mathrm{mm}$. Only one sample $(490-5-7,9 \mathrm{~cm})$ has a significant amount of green pellets of less than $0.16 \mathrm{~mm}$ in size, and only a few green grains between $0.5 \mathrm{~mm}$ and $4 \mathrm{~mm}$ were hand-picked from the samples at Sites 489 and 490. Thin sections of these large green grains show an irregular structure including traces of the initial substrate such as altered quartz and etched tests of planktonic microfossils. The initial hosts of glauconitization were probably composite calcareous muddy, silty particles. A thin, irregular, darker brownish crust surrounds these grains. Carbonaceous particles and well-crystallized gypsum may also be present in this large fraction (see Tables 1 and 2).

The 0.16 to $0.5 \mathrm{~mm}$ fraction is next paramagnetically divided into attractable and nonattractable fractions, using a 0.6-A intensity (Fig. 5). The attractable fractions are composed almost solely of glaucony. Most of the green grains show a less-evolved, lighter green crust. This observation provides evidence for the strictly authigenic nature of the grains: the soft external film would have been removed by a long transport process. Moreover, the variability in size of the green grains, their different stages of evolution (from nascent to littleevolved), the absence of detrital quartz grains of equivalent size, and the absence of a break of sedimentation linked with the glauconitic horizons lead us to the conclusion that green grains in Leg 66 sediments were formed in situ regardless of depth. The most frequently recognizable hosts for glauconitization are foraminiferal tests. According to Giresse et al. (1980), this kind of substrate, on a continental shelf, produces small, rounded green grains and suggests a glauconitization process essentially confined to depths of more than 150 meters.

Coprolites are also present, and although we cannot identify their origin at the moment, they may have been formed in situ. The presence of glauconitized micas, sometimes common (Table 2), might imply redeposition by bottom currents from the direction of the coast, but of course the mica may have been transported as mica flakes together with the rest of the fine fraction prior to glauconitization. The presence of iron oxides and oxidized crusts on some quartz grains cannot be explained at the moment. They may represent some pollution of samples during handling.

In summary the glaucony appears to be authigenic in origin (1) because the necessary preliminary substrates in deposition were available in situ (2) because no traces of transportation are visible on the green grains, and (3) because the granulometry of the authigenic green grains 
Table 1. Characteristics of Leg 66, glauconies, Holes 489 and 489A.

\begin{tabular}{|c|c|c|c|c|c|c|}
\hline $\begin{array}{c}\text { Sample } \\
\text { (level in } \mathrm{cm} \text { ) }\end{array}$ & $\begin{array}{l}\text { Depth } \\
(\mathrm{m})\end{array}$ & $\begin{array}{l}\text { Glaucony } \\
\text { (wt. \%) }\end{array}$ & $\begin{array}{c}\text { Foraminifers } \\
((\%)\end{array}$ & Initial Substrate & $\begin{array}{c}\text { X Rays } \\
(\tilde{A})\end{array}$ & \\
\hline \multicolumn{7}{|l|}{ Hole 489} \\
\hline $1-1,10$ & 0.10 & 10 & ve & & & \\
\hline $1-1,121$ & 1.21 & 15 & 5 & molds + coprolites? & $\mathrm{AH} 11.9$ & $\mathrm{~K}$-Ar dating \\
\hline $1-2,110$ & 2.60 & 40 & t & molds + coprolites? & $\begin{array}{l}\text { AH } 11.3 \\
\text { AL } 11.9\end{array}$ & r gypsum \\
\hline $1-3,61$ & 3.61 & 40 & c & & $\mathrm{AH} 11.5$ & gypsum \\
\hline $1-4,65$ & 5.15 & 41 & C & $\begin{array}{l}\text { molds + coprolites VC } \\
+\mathrm{r} \text { micas }\end{array}$ & $\begin{array}{l}\mathrm{AH} 10.8 \\
\mathrm{AL} 12.1\end{array}$ & $\begin{array}{l}\text { K-Ar dating } \\
\text { gypsum }\end{array}$ \\
\hline \multicolumn{7}{|l|}{ Hole 489A } \\
\hline $1-1,15$ & 0.15 & 25 & $\mathrm{vC}$ & $+r$ micas & АН 11.9 & \\
\hline $23-4,47$ & 221.97 & 0 & 0 & & & \\
\hline $23-4,133$ & 222.83 & $\mathrm{r}$ & 0 & small coprolites + ? & & charcoal \\
\hline
\end{tabular}

Table 2. Characteristics of Leg 66 glauconies, Holes 490, 492, and 492A.

\begin{tabular}{|c|c|c|c|c|c|c|}
\hline $\begin{array}{c}\text { Sample } \\
(\text { level in } \mathrm{cm} \text { ) }\end{array}$ & $\begin{array}{l}\text { Depth } \\
(\mathrm{m})\end{array}$ & $\begin{array}{l}\text { Glaucony } \\
\text { (wt. } \% \text { ) }\end{array}$ & $\begin{array}{c}\text { Foraminifers } \\
(\%)\end{array}$ & Initial Substrate & $\begin{array}{l}\text { X Rays } \\
(\dot{A})\end{array}$ & Remarks \\
\hline \multicolumn{7}{|l|}{ Hole 490} \\
\hline $1-1,72$ & 0.72 & 60 & 0 & pp molds & & \\
\hline $1-2,96$ & 2.50 & 60 & 30 & $\mathrm{pp}$ molds & AH 12.0 & $\mathrm{~K}$ \\
\hline $3-6,117$ & 27.20 & 20 & 0 & VC molds + others & $\mathrm{AH} 11.3$ & Fe oxides $\mathrm{C}$ \\
\hline $5-7,9$ & 46.60 & 20 & $\mathrm{r}$ & molds + coprolites & AH 11.1 & $\mathrm{~K}$ \\
\hline $18-3,132$ & 165.30 & 0 & & & & \\
\hline $20-4,7$ & 185.10 & $\mathrm{r}$ & & molds & & authigenic calcite \\
\hline $25-4,12$ & 232.10 & 7 & & coprolites + molds & & Fe oxides + charcoal \\
\hline $25-4,31$ & 232.30 & 7 & & & & $\mathrm{Fe}$ oxides + charcoal \\
\hline $27-2,91$ & 248.90 & 5 & $\mathrm{r}$ & molds + coprolites + micas $r$ & & charcoal \\
\hline $28, \mathrm{CC}, 5$ & 254.50 & 7 & $\mathrm{r}$ & $\mathrm{r}$ molds + ? & & gypsum \\
\hline $29-2,34$ & 267.34 & 12 & & $\mathrm{C}$ molds $+\mathrm{C}$ micas & AL 11.8 & \\
\hline $37-3,11$ & 335.10 & 0 & & & & \\
\hline $52-1,37$ & 465.40 & 0 & & & & \\
\hline \multicolumn{7}{|l|}{ Hole 492} \\
\hline $3-2,78$ & 15.30 & 30 & $r$ & molds + coprolites & & charcoal \\
\hline $6-2,55$ & 43.60 & 6 & $\mathrm{r}$ & molds $+C$ micas & $\mathrm{AH} 11.6$ & gypsum \\
\hline \multicolumn{7}{|l|}{ Hole $492 \mathrm{~A}$} \\
\hline $4-1,84$ & 9.80 & 70 & C & molds $+r$ micas & AH 10.9 & K \\
\hline $7-2,41$ & 29.90 & $\mathrm{r}$ & $r$ & molds + coprolites & & \\
\hline
\end{tabular}

Note: For explanation and abbreviations, see Table 1.

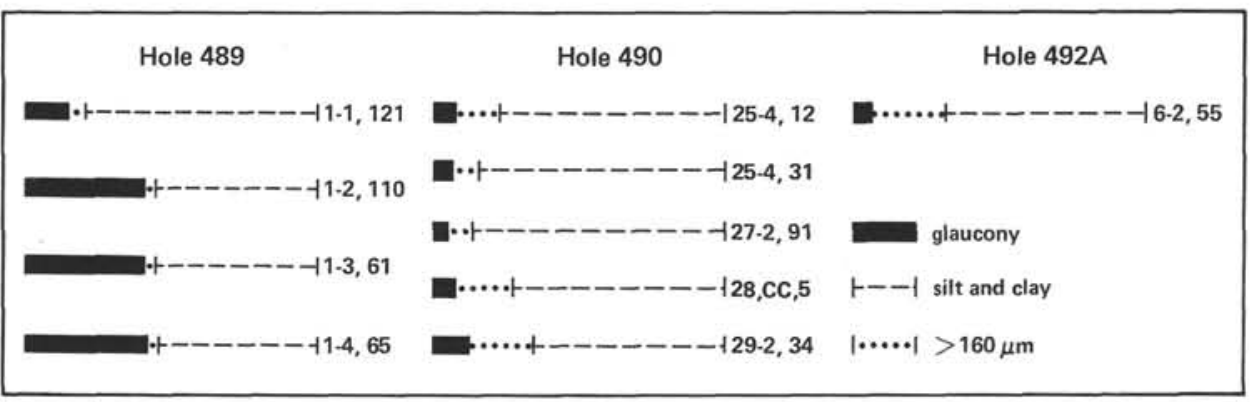

Figure 5. Proportion of glaucony, sand, and finer fraction in several samples from Leg 66. (Level in cm.)

and of the remaining sediment are not consistent with processes of transportation.

\section{Analytical Results}

The green grains were ultrasonically cleaned in dilute acetic acid, then washed in deionized water and dried at less than $70^{\circ} \mathrm{C}$. Paramagnetic fractionation of each sample permits elimination of the highly magnetic fraction and, frequently, of impurities, and allows us to select homogeneous fractions for analysis.
The $<35 \mu \mathrm{m}$ fraction was X-rayed. The clay fraction appears very homogeneous within all cores and across sites. It corresponds to a mixing of 40 to $50 \%$ illite with 60 to $50 \%$ kaolinite, usually badly crystallized: the (001) peak is open toward the higher sheet thicknesses. A small to very small peak is also present at $14 \AA$.

The small quantity of available glaucony in each fraction has led to the use of a new procedure for X-ray analysis on powder mounts. The principle is as follows: nearly $10 \mathrm{mg}$ of pellets are crushed in an agate mortar 
with a few drops of acetone. The resulting green mud is arranged as a very thin film on a glass slide, and dries. The thinness of the film diminishes the fluorescence of iron, which is usually rather high with a copper tube. The slide is then stuck with a small drop of oil to an aluminum stand adapted to a running system, in such a way that the slide surface is in the same plane as the Xrays. The glass slide with the powder can be stored and reused.

Examples of diffractograms so obtained are shown in Figure 6. The most evolved glaucony is that one presented at the top; the less evolved type is the lowest diffractogram. The most commonly used criterion to characterize glauconitic minerals is the position of the middle of the (001) diffraction peak. In order to correct for possible change in the calibration of the machine it is also instructive to consider the distance $d$ between the (001) peak and the (020) peak, the latter being very stable in position. These data confirm that the glauconitic minerals are characteristic of a nascent to little-evolved glaucony (Odin and Matter, in press). No evolved to highly evolved minerals are present in any fraction. Thus the duration of evolution of all the grains was short-a few thousand years.

Chemical analyses were also undertaken. The potassium content is fairly uniform in all the glaucony, although it clearly correlates with the mineralogical composition as determined by the position of the (001) peak (Fig. 5). The low overall range in potassium content is explained by the originally potassic nature of the substrates.

We have also obtained a complete chemical analysis on the most evolved grains. The results are shown in Table 3. Their chemical composition is very similar to that of the common ancient glaucony, except for an anomalously high water content probably linked with the presence of uncrystallized material.

The balance between alteration of the initial host and crystallization of authigenic minerals is better shown by isotopic analyses. First, we must remember that the initial host contains radiogenic isotopes at the time of glauconitization (Tisserant and Odin, 1979; Odin and Dodson, in press). Such was the case in the present study, as shown by the apparent ages of the $<35 \mu \mathrm{m}$ fraction of the Hole 489 samples (Table 4), which are muds forming the first infilling of foram tests and also the main component of coprolites. When glauconitization occurs the apparent age drops but may reach zero only when the process is complete-i.e., when authigenic minerals are nearly $6 \%$ potassium and there has been complete removal of the host material. The data in Table 4 clearly show that zero apparent age has never been obtained for these green grains. More important, however, is that the apparent ages demonstrate conclusively that the grains are not inherited from nearby older outcrops that were undergoing erosion.

In summary, isotopic analyses show that the glaucony is not reworked in situ, and the sedimentological

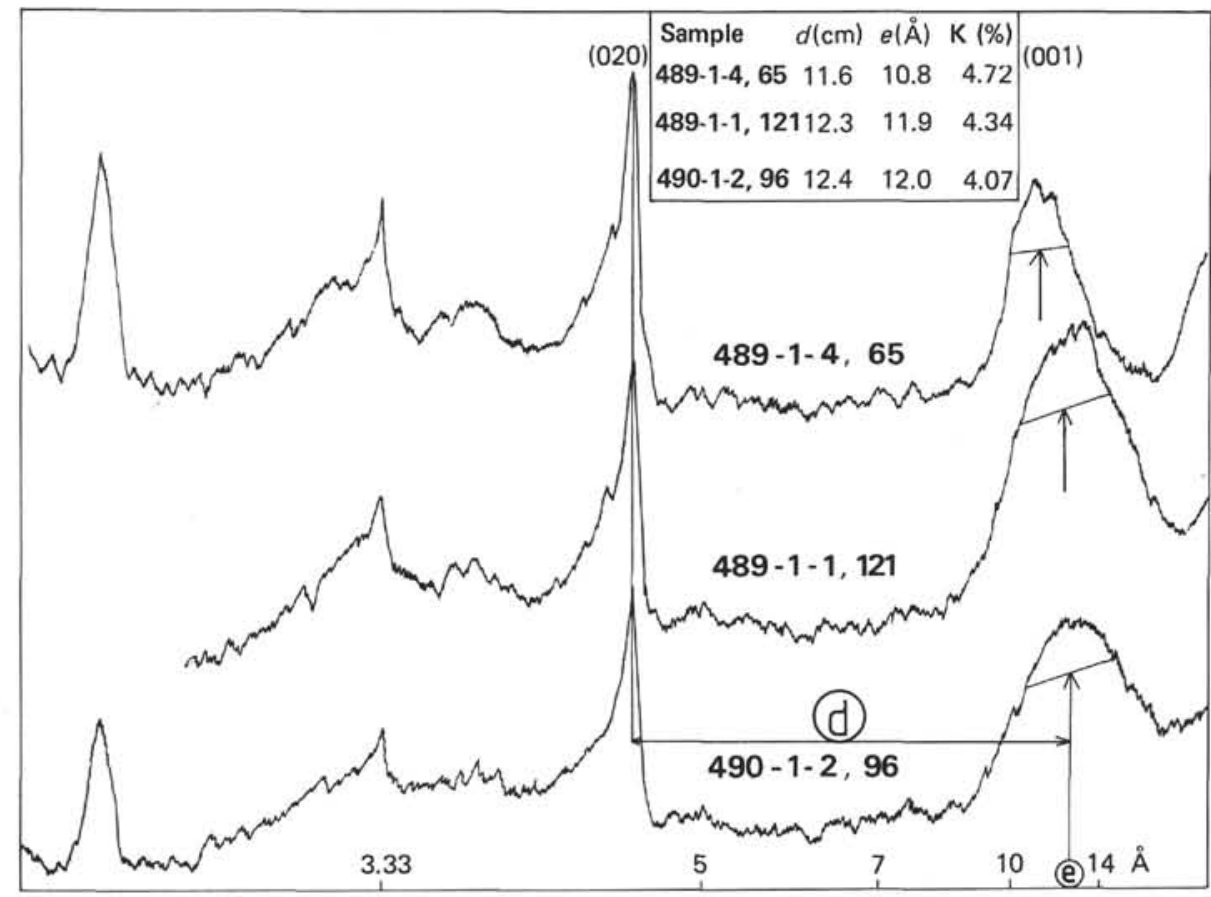

Figure 6. X-ray diffractograms of three samples of pure glaucony. Mineralogical authigenic components may be characterized by three criteria: the position of the middle of the (001) peak $e$, the distance between the middle of the (001) peak and the rather constant $(020)$ peak $d$, and the potassium content. (X-ray emission was done with a copper tube; $1 \mathrm{~cm}$ on the original diagram is $1^{\circ}$. Diffraction was done on powder mounts. No traces of the initial substrate are shown in spite of their very probable presence in the grains, evidenced by remaining radiogenic argon and high "water" content. Sample levels are in cm.) 
Table 3. Chemical composition of more evolved Leg 66 glaucony.

\begin{tabular}{|c|c|c|c|c|c|c|c|c|c|c|c|c|c|c|}
\hline Sample $489-1-4,65 \mathrm{~cm}$ & $\mathrm{SiO}_{2}$ & $\mathrm{Al}_{2} \mathrm{O}_{3}$ & $\mathrm{Fe}_{2} \mathrm{O}_{3}$ & $\mathrm{FeO}$ & $\mathrm{MnO}$ & $\mathrm{MgO}$ & $\mathrm{CaO}$ & $\mathrm{Na}_{2} \mathrm{O}$ & $\mathrm{K}_{2} \mathrm{O}$ & $\mathrm{TiO}_{2}$ & $\mathrm{P}_{2} \mathrm{O}_{5}$ & $\mathrm{H}_{2} \mathrm{O}^{+}$ & $\begin{array}{l}\mathrm{H}_{2} \mathrm{O}^{-} \\
\left(105^{\circ} \mathrm{C}\right)\end{array}$ & Total \\
\hline $\mathrm{AH}$ & 47.8 & 5.75 & 19.8 & 1.8 & $\mathrm{t}$ & 3.22 & 0.65 & 0.2 & 5.61 & 0.2 & 0.15 & 7.65 & 7.1 & 99.93 \\
\hline
\end{tabular}

Note: The sample was weighed without preliminary drying and analyzed by M. Lenoble. Water content is much too high for both constitution $\left(\mathrm{H}_{2} \mathrm{O}^{+}\right)$and inbibition $\left(\mathrm{H}_{2} \mathrm{O}^{-}\right)$parts.

Table 4. K-Ar data on Leg 66 glauconies and clay fraction of sediments.

\begin{tabular}{|c|c|c|c|c|c|}
\hline \multirow{2}{*}{$\begin{array}{c}\begin{array}{c}\text { Sample } \\
\text { (level in cm) }\end{array} \\
489-1-1-121 \\
489-1-4-65\end{array}$} & \multicolumn{2}{|c|}{ Potassium } & \multirow{2}{*}{$\begin{array}{c}\begin{array}{c}\text { Radiogenic/ } \\
\text { Total Ar } \\
(\%)\end{array} \\
8\end{array}$} & \multirow{2}{*}{$\begin{array}{c}\begin{array}{c}\text { Radiogenic Ar } \\
\left(\mathrm{nl} \cdot \mathrm{g}^{-1}\right)\end{array} \\
0.60\end{array}$} & \multirow{2}{*}{$\begin{array}{c}\begin{array}{c}\text { Apparent age } \\
(\mathrm{Ma} ; \mathrm{ICC})\end{array} \\
3.6 \pm 0.9\end{array}$} \\
\hline & gl. $\mathrm{AH}$ & FP 4.34 & & & \\
\hline $489-1-4-65$ & gl. AH & $\begin{array}{l}\text { FP } 4.72 \\
\text { XF } 4.66\end{array}$ & 13 & 0.93 & $5.1 \pm 0.8$ \\
\hline $490-1-2-96$ & gl. AH I & FP 4.07 & 9 & 0.49 & $3.1 \pm 0.7$ \\
\hline $490-5-7-9$ & gl. AH I & FP 4.46 & 13 & 0.55 & $3.2 \pm 0.5$ \\
\hline $492 \mathrm{~A}-4-1-84$ & gl. AH & FP 4.71 & & & \\
\hline $\begin{array}{l}489-1 \text { clay }(< \\
\text { reference mate }\end{array}$ & $\begin{array}{l}10 \mu \mathrm{m}) \\
\text { rial GL-O }\end{array}$ & $\begin{array}{r}\text { FP } 2.02 \\
6.59\end{array}$ & 33 & $\begin{array}{c}3.69 \\
24.8\end{array}$ & $46.4 \pm 2.9$ \\
\hline
\end{tabular}

Note: gl. $=$ glaucony, $\mathrm{ICC}=$ conventional constants, $\mathrm{FP}=$ flame photometry, $\mathrm{XF}$ $=\mathrm{X}$-ray fluorescence. The apparent age of the detrital clay fraction is inherited and is probably similar to that of the initial substrate of glauconitization. The apparent ages of the glauconies demonstrate once more the presence of part of the initial radiogenic argon as it might have been foreseen from their level of evolution. The apparent ages cannot be related to the epoch of genesis. Potassium analyses were done by M. Lenoble; Argon analyses were done by M. G. Bonhomme, Université de Strasbourg.

observations indicate that inheritance from shallower depth is unlikely.

\section{DISCUSSION}

Considering the entire East Pacific margin from Canada to Panama, glauconitization seems to occur in two depth zones, (1) from 100 to 500 meters near the continent and (2) from 1000 to 2000 meters away from the continental shelf. (The uncommon glaucony-poor samples at 4000 to $6000 \mathrm{~m}$ have not yet been investigated but are probably related to transport). The second zone poses a question: Why do green grains occur so much deeper than the commonly recognized zone for genesis of glaucony in the range 100 to 500 meters? In response, we consider two hypothetical explanations.

\section{Subsidence}

Our study of the green grains collected from Sites 489, 490, and 492 of Leg 66 indicates that they formed in situ. The Leg 66 area is, of course, very active tectonically, a factor common to all the deep glaucony occurrences along the East Pacific margin and on the Scotia Ridge, the Chatham Rise, and off Japan. Although the Japan Trench glauconies have not been studied in detail (Scientific Party, 1980), we consider it significant that Cadet (personal communication, 1980) finds very abundant glaucony at great depths to be associated with faunas characteristic of shallower depths. This author concludes that the deep glauconitic sediments formed at shallower depths that increased as the result of an active and rapid process of subsidence. This hypothesis may also explain the Quaternary glauconies off Central America. If correct, several conclusions follow:

1) Glaucony present at great depth $(1000-2000 \mathrm{~m})$ in numerous other sites along the North American Pacific margin (Figs. 3 and 4) indicates that subsidence occurred for all these outcrops.

2) Because deep glaucony is present in levels dated as Miocene, Pliocene, and Pleistocene as well as in subsurface sediments, the assumed deepening must have taken place in very recent times.

3) If the subsidence hypothesis is correct, the deepening of the seafloor can be measured by the difference between the commonly accepted depth of glauconitization, 100 to 500 meters, and the present depth of occurrence; the latter varies from 1000 to 2000 meters, except for one point at 3800 meters off Los Angeles and another at nearly 2500 meters off the Cabo San Lucas. Nevertheless, when glaucony is cited at depths greater than 2000 meters, a special study of the outcrop must be done; at the moment, transport is the most likely hypothesis.

In the case of the sites drilled off Point Arguello and off Ometepec, it is implied that subsidence was much more effective for the sites farthest from the coast and nearest the zone of subduction.

At the moment, we have no argument against subsidence. Further evidence is necessary before such a hypothesis can be verified; still, it may be kept in mind to show that $a$ contrario the raising of the seafloor has a low probability.

\section{Glaucony Genesis at Great Depth}

A second hypothesis, which we have discussed, is glauconitization at great depth. The known constraints for glauconitization do not require a shallow depth. The presence of initial substrate, the renewing of useful ions, and time necessary for evolution of the substrate may well be encountered at depths greater than 500 meters. The tendency for glauconitization on such seafloor highs as rises, ridges, and seamounts is well known. These sites probably favor slower sedimentation and the renewing of ions. The remaining condition, presence of adequate substrate, may well prevail if the benthic life produces coprolites or if the planktonic life produces tests whose chambers create a favorable microenvironment. On Leg 66 deep glaucony was linked to the presence of foraminiferal tests; thus initial substrate is not a problem provided that the depth of the CCD and of the seafloor are adequate. Such is the case for the present sediments, although the occurrence of glaucony at 6000 meters on Leg 67 poses a problem. 
As a result there is no definitive argument, against the possibility of glauconitization at great depth, especially if deep currents may be postulated. If this hypothesis receives further support, we will have shown that the commonly accepted view by which glaucony is assigned a depth of 100 to 500 meters must be modified.

In order to obtain new data a study of glauconitization on the borders of the Pacific from Central America to Alaska, Japan, and, possibly, the Ladrones Islands is now under way.

\section{ACKNOWLEDGMENTS}

This work was achieved within the framework and with the financial support of the ATP IPOD of the CNRS (Contract 42-32). We address our thanks to Michel Bonhomme for obtaining the argon results. We are also deeply grateful to Jeremy Leggett for reading our manuscript and turning it into the language of Shakespeare.

\section{REFERENCES}

Bell, D. L., and Goodell, H. G., 1967. A comparative study of glauconite and the associated clay fraction in modern marine sediments. Sedimentology, 9:169-202.

Collet, L. W., 1908. Les dépôts marins. La Glauconie: Paris (Doin), pp. 132-194.

Cullen, D. J., 1967. The age of glauconite from the Chatham Rise, East of New Zealand. N. Z. J. Mar. Freshwater Res., 1:399-406.

Curray, J. R., Moore, D. G., et al., in press. Init. Repts. DSDP, 64: Washington (U.S. Govt. Printing Office).

Galliher, E. W., 1935. Geology of glauconite. Am. Assoc. Pet. Geol. Bull., 19:1569-1601.

Giresse, P., Lamboy, M., and Odin, G. S., 1980. Evolution géométrique des supports de glauconitisation, reconstitution de leur paléo-environnement. Oceanologia Acta, 3:251-260.

Hein, J. R., Allwardt, A. O., and Griggs, G. B., 1974. The occurrence of glauconite in Monterey Bay, California. Diversity, origins and sedimentary environmental significance. J. Sediment. Petrol., 44: 562-571.

Karig, D. E., Ingle, J. C., Jr., et al., 1975. Init. Repts. DSDP, 31: Washington (U.S. Govt. Printing Office).

Kulm, L. D., von Huene, R., et al., 1973. Init. Repts. DSDP, 18: Washington (U.S. Govt. Printing Office).
Murray, J. W., and Mackintosh, E. E., 1968. Occurrence of interstratified glauconite-montmorillonoid pellets, Queen Charlotte Sound, British Columbia. Can. J. Earth Sci., 5:243-247.

Norris, R. M., 1964. Sediments of Chatham Rise. Bull. N. Z. Dep. Sci. Ind. Res., Vol. 159.

Odin, G. S., 1972. Observations nouvelles sur la glauconie en accordéon (vermicular pellets), description du processus de genèse par néoformation. Sedimentology, 19:285-294.

, 1973. Répartition, nature minéralogique et genèse des granules verts des sédiments marins actuels. Sci. Terre, Nancy, 18 (1):79-94.

1975a. De glauconarium constitione, origine, aetateque [Ph.D. dissert.]. Université Pierre et Marie Curie, Paris. 1975b. Migration du fer des eaux continentales jusqu'aux eaux océaniques profondes. C. R. Hedb. Seances Acad. Sci., Ser. D, 281:1665-1668.

Odin, G. S., and Dodson, M. H., in press. Zero isotopic age of glauconies. In Odin, G. S. (Ed.), Numerical Dating in Stratigraphy: New York (Wiley).

Odin, S. G., and Létolle, R., 1980. Glauconitization and phosphatization environments: A tentative comparison. In Bentor, Y. K. (Ed.), Marine Phosphorites: Soc. Econ. Pal. Min. Spec. Publ., 29:227-237.

Odin, G. S., and Matter, A., in press. De glauconiarum origine. Sedimentology.

Pratt, W. L., 1963. Glauconite from the sea floor off Southern California. In Miller, R. L. (Ed.), Essays in Marine Geology in Honor of K. O. Emery: Los Angeles (University of Southern California Press), pp. 97-119.

Ross, D. A., 1971. Sediments of the Northern Middle America Trench. Geol. Soc. Am. Bull., 82:303-322.

Scientific Party, 1980. Init. Repts. DSDP, 56, 57: Washington (U.S. Govt. Printing Office).

Shipboard Scientific Party, in press. Site 467: San Miguel Gap. In Yeats, R. S., Haq, B. U., et al., Init. Repts. DSDP, 63: Washington (U.S. Govt. Printing Office), 23-112.

Tisserant, D., and Odin, G. S.,1979. Datation isotopique de la glauconie miocène d'A frique du Nord-Ouest. C. R. Somm. Soc. Géol. Fr., 4:188-190.

Velde, B., and Odin, G. S., 1975. Further information related to the origin of glauconite. Clays Clay Miner., 23:376-381.

Yeats, R. S., Haq, B. U., et al., in press. Init. Repts. DSDP, 63: Washington (U.S. Govt. Printing Office). 